\title{
ANALISIS HUKUM TERHADAP UPAYA PERLINDUNGAN DAN PEMBERDAYAAN NELAYAN KECIL DAN PEMBUDI DAYA IKAN
}

\author{
Mohamad Ismail Hairun \\ Kementerian Kelautan dan Perikanan Kota Tarakan \\ P2sdkpbitung@gmail.com
}

\begin{abstract}
Most fishermen and fish breeders live in poverty, are poorly educated and live in an atmosphere of business uncertainty. As part of citizens, they are constitutionally entitled to the protection and empowerment of the state. Therefore, the Republic of Indonesia Law No. 7 of 2016 concerning the Protection and Empowerment of Fishermen, Fish Farmers, and Salt Farmers was born. Two problem statements are raised, namely first; Legis ratio of protection and empowerment of fishermen, and secondly; a form of protection and empowerment of fishers and fish breeders

The research method used is a normative juridical research method because it uses primary and secondary legal materials with a qualitative analysis approach.

Based on the results of the study can be concluded first; Legis ratio of protection and empowerment of fishermen and fish cultivators because fishermen and fish breeders are generally categorized as poor, low-educated, and powerless. As part of citizens who are entitled to fair legal recognition, guarantee, protection and certainty, and equal treatment before the law. Philosophically protect fishermen and fish breeders in conducting their business so that they are free or avoiding various problems and subsequently increase capacity in various aspects that benefit them.

Both forms of protection for fishermen and fish farmers in the form of providing infrastructure and means of production of business activities, in the form of fishing gear, ships and/or ports, land and water ponds, and irrigation channels, provide guarantees of business certainty, guarantees of risk of catching and cultivating fish and elimination of high-cost economic practices. While the empowerment of fishermen and fish farmers is done by increasing the capacity of fishermen and fish farmers through education and training, fostering a spirit of self-sufficiency through counseling and mentoring, providing opportunities and opportunities for marketing, capital, increasing human resources, providing financing and capital facilities.
\end{abstract}

Keywords; Protection, Empowerment, Fishermen and Fish breeders

\section{A. Pendahuluan}

\section{Latar Belakang}

Nelayan sebagai subjek utama dalam pemanfaatan dan pengelolaan sumber daya kelautan dan perikanan perlu mendapat perhatian. Konvensi ILO Nomor 188 Tahun 2007 tentang Pengaturan Bekerja di Bidang Perikanan (the Work in Fishing Convention) menyatakan bahwa pekerjaan di bidang perikanan khususnya penangkapan sebagai jenis pekerjaan yang berbahaya dibandingkan dengan jenis pekerjaan lainnya. Pekerjaan tersebut memiliki resiko terjadinya pelanggaran hak-hak pekerja di atas kapal perikanan dan tindak pidana yang mengancam kelestarian sumber daya kelautan dan perikanan, 
seperti illegal, unreported, and unregulated fishing dan penangkapan biota-biota laut yang dilindungi. Selain itu, nelayan merupakan pihak yang berkontribusi sebagai penyedia produk hayati kelautan dan perikanan, baik untuk kebutuhan konsumsi maupun industri pengolahan.

Negara bertanggung jawab melindungi segenap bangsa Indonesia dan seluruh tumpah darah Indonesia, memajukan kesejahteraan umum, mencerdaskan kehidupan bangsa, serta mewujudkan keadilan sosial bagi seluruh rakyat Indonesia sesuai dengan amanat Pancasila dan Undang-Undang Dasar Negara Republik Indonesia Tahun 1945. Salah satu filosofi dasar pembangunan bangsa ialah mewujudkan keadilan sosial bagi seluruh rakyat Indonesia. Oleh karena itu, setiap warga negara Indonesia berhak dan wajib sesuai dengan kemampuannya ikut serta dalam pengembangan usaha untuk meningkatkan kesejahteraan, khususnya di bidang Perikanan.

Sejalan dengan amanat Pancasila dan Undang-Undang Dasar Negara Republik Indonesia Tahun 1945, salah satu tujuan pembangunan Perikanan dan kelautan diarahkan, antara lain untuk meningkatkan sebesar-besarnya kesejahteraan Nelayan, dan Pembudi Daya Ikan,. Selama ini Nelayan, dan Pembudi Daya Ikan, tersebut telah memberikan kontribusi yang nyata dalam pembangunan Perikanan dan kelautan serta pembangunan ekonomi masyarakat pesisir dan perdesaan ${ }^{1}$

Kehidupan nelayan di negeri ini didera sederet persoalan krusial. Itu berupa serbuan ikan impor dari negara lain yang membanjiri pasar domestik. Juga masalah persediaan BBM untuk melaut. Profesi nelayan kini masih terpuruk karena insentif dan program pemberdayaan nelayan kurang menjangkau secara luas. Para nelayan sering tidak bisa memenuhi biaya operasional. Akibatnya, waktu menganggur nelayan semakin panjang.

Kegiatan perlindungan dan pemberdayaan nelayan,dan pembudi daya ikan, erat kaitannya dengan kegiatan ekonomi nelayan, pembudi dan daya ikan, guna memenuhi kebutuhan hidup, baik primer, sekunder, maupun tersier. Untuk dapat memperoleh hasil yang optimal, maka kegiatan ekonomi harus dilakukan secara efisien, dimana penggunaan input (sarana produksi) yang rendah

\footnotetext{
${ }^{1}$ Alinea ke dua Penjelasan Umum Undang-Undang No. 7 Tahun 2016 Tentang Perlindungan dan pemberdayaan Nelatan,Pembudidaya Ikan dan Petambak Garam
} 
akan memperoleh output (hasil) yang besar. Namun, efisien tidak boleh mengesampingkan rasa keadilan, khususnya untuk nelayan buruh, dan pembudi daya ikan kecil,. Mereka tetap harus memperoleh upah/bagi hasil yang wajar dan memenuhi rasa keadilan untuk kebutuhan rumah tangganya.

Kegiatan nelayan dan pembudi daya ikan dalam menangkap ikan dan membudidayakan ikan harus terus-menerus dilakukan, berkembang dan tidak stagnan. Kegiatan tersebut harus mampu menyesuaikan dengan perkembangan zaman dan teknologi, agar dapat memenuhi kebutuhan hidup anggota keluarganya. Selain itu, kegiatan perlindungan dan pemberdayaan nelayan, dan pembudi daya ikan, harus mampu menyesuaikan dengan tradisi dan budaya yang selama ini berkembang di masyarakat secara turun-temurun. Budaya dan tradisi tersebut merupakan kearifan lokal yang mampu bertahan dalam modernisasi pembangunan, sehingga keberadaannya perlu diperhatikan.

Nelayan dan pembudi daya ikan dalam melakukan kegiatan usaha sangat tergantung pada keberadaan sumber daya ikan, sehingga kualitas lingkungan, baik yang berada di laut, pesisir, dan perairan harus terjaga. Kualitas lingkungan sangat dipengaruhi oleh aktivitas masyarakat yang ada di daerah hulu, tengah, dan hilir, sebuah kawasan karena merupakan satu kesatuan ekosistem lingkungan. Oleh karena itu, penyelenggaraan perlindungan dan pemberdayaan nelayan, dan pembudi daya ikan, wajib memperhatikan asas kelestarian lingkungan.

\section{Metode Penelitian}

Jenis Penelitian yang dugunakan adalah penelitian Hukum normative Penelitian hukum dilakukan untuk mencari pemecahan atas isu hukum yang timbul. Hasil yang hendak dicapai adalah memberikan preskripsi mengenai apa yang seyogianya. ${ }^{2}$ Pendekatan yang digunakan adalah pendekatan peraturan perundang-undangan (Statute approach ) dan pendekatan konseptual (conceptual approach).

\footnotetext{
${ }^{2}$ Peter Mahmud Marzuki, op.cit.h. 89.
} 


\section{B. Pembahasan}

\section{Ratio Legis Perlindungan Dan Pemberdayaan Terhadap Nelayan DanPembudi Daya Ikan}

Nelayan kecil, dan pembudi daya ikan kecil, pada umumnya dikategorikan miskin, berpendidikan rendah, dan tidak berdaya juga bagian dari warga Negara yang berhak atas pengakuan, jaminan, perlindungan, dan kepastian hukum yang adil, serta perlakuan yang sama dihadapan hukum. Secara konstitusional, hal ini dijamin di dalam alinea ke-4 pembukaan UUD Negara Republik Indonesia Tahun1945 yakni untuk melindungi segenap bangsa Indonesia dan seluruh tumpah darah Indonesia dan untuk memajukan kesejahteraan umum, serta mencerdaskan kehidupan bangsa. Kemudian di dalam batang tubuh UUD Negara Republik Indonesia Tahun 1945 Pasal 28H menyebutkan hak setiap warga Negara untuk memperoleh hidup sejahtera lahir dan batin, bertempat tinggal, dan mendapatkan lingkungan hidup baik dan sehat serta berhak memperoleh pelayanan kesehatan. Berdasarkan ketentuan tersebut dapat dipahami bahwa nelayan dan pembudi daya adalah bagian dari warga berhak memperoleh hidup sejahtera lahir dan batin, Disamping itu juga berhak mendapat kemudahan dan perlakuan khusus untuk memperoleh kesempatan dan manfaat yang sama guna mencapai persamaan dan keadilan, serta hak atas jaminan sosial yang memungkinkan pengembangan dirinya secara utuh sebagai manusia yang bermartabat.

Dengan demikian, upaya perlindungan dan pemberdayaan kepada nelayan, dan pembudi daya ikan, merupakan bagian dari hak asasi manusia sebagai upaya konkrit Negara (pemerintah) dalam memenuhi hak dasar warga negaranya. Perlindungan hak dasar ini juga mempunyai makna penting dalam upaya mewujudkan dua sisi ketahanan pangan di Indonesia. Di satu sisi adalah upaya memenuhi kebutuhan pangan yang bergizi, beragam dan berimbang dengan harga yang terjangkau oleh rakyatnya. Tentu saja dengan peningkatan daya beli masyarakat, maka akan meningkatkan ketahanan pangan keluarga dan masyarakat. Di sisi lain, upaya strategi pembangunan tersebut dianggap berhasil karena adanya pertumbuhan ekonomi yang cepat dan merata pada lapisan masyarakat miskin. Strategi pembangunan nasional dengan target utama penduduk miskin yang tinggal dan bekerja di sektor perikanan dan 
pesisir, dapat berhasil meningkatkan produksinya melalui pemanfaatan sumber daya yang melimpah secara berkelanjutan, dimana bumi dan air serta kekayaan alam yang terkandung di dalamnya dikuasai oleh negara dan dipergunakan untuk sebesar- besar kemakmuran rakyat.

Makna perlindungan yaitu perbuatan meindungi, memposisikan atau menolong obyek, dalam hal ini nelayan, dan pembudi daya ikan atau dapat juga berarti mengkondisikannya pada posisi yang aman atau terhindar dari berbagai hal yang merugikan, dari risiko, dan berbagai permasalahan. Setelah dapat pastikan nelayan, dan pembudi daya ikan, sudah dalam situasi dan kondisi yang aman atau kondusif bagi mereka untuk melakukan usahanya, tugas selanjutnya adalah memberdayakan mereka.

Pemberdayaan memiliki makna suatu proses, cara, perbuatan memberdayakan, membuat menjadi berdaya, mampu, memiliki kapasitas. Jadi nantinya diharapkan nelayan, dan pembudi daya ikan, lebih mampu bukan hanya sekedar mengatasi permasalahan, namun juga lebih memiliki nilai lebih, berhasil, dan memiliki kemandirian dalam menjalankan usahanya.

Secara filosofis dapat dijelaskan bahwa ada suatu kepentingan untuk membuat kondisi yang kondusif dengan memberikan perlindungan bagi para nelayan, dan pembuidi daya ikan, dalam melakukan usahanya, sehingga bebas atau terhindar dari berbagai permasalahan dan selanjutnya meningkatkan kapasitas dalam berbagai aspek yang menguntungkan mereka.

Sementara itu dari aspek sosiologisnya Indonesia merupakan negara kepulauan, dimana sebagian besar nelayan adalah nelayan kecil dengan tingkat kesejahteraan dan pendidikan yang rendah. Hingga kini kondisi nelayan dan pembudidaya ikan di negeri ini memang masih diwarnai dengan berbagai masalah pelik. Kehidupan nelayan didera sederet persoalan krusial. Antara lain masalah serbuan ikan impor dari negara lain yang membanjiri pasar domestik, masalah persediaan BBM untuk melaut. Profesi nelayan kini masih terpuruk karena insentif dan program pemberdayaan nelayan kurang menjangkau secara luas. Para nelayan sering tidak bisa memenuhi biaya operasional. Akibatnya, waktu menganggur nelayan semakin panjang.

Dari aspek yuridis bahwa Undang-undang Nomor 45 Tahun 2009 tentang perubahan atas Undang-Undang Nomor 31 Tahun 2004 tentang Perikanan telah 
mengamanatkan perlindungan dan pemberdayaan kepada Nelayan kecil dan Pembudi Daya Ikan Kecil dalam Bab X dari Pasal 60-Pasal 64. Namun dalam pelaksanaannya pemerintah belum membuat aturan pelaksanaan dari ketentuan tersebut yakni Peraturan Pemerintah mengenai perlindungan dan pemberdayaan kepada nelayan kecil dan pembudi daya ikan kecil sebagaimana tercantum dalam amanat UU Perikanan. UU Perikanan belum mengatur mengenai sarana produksi, lahan, jaminan resiko akibat kecelakaan bencana bagi nelayan dan pembudi daya ikan. Substansi yang tidak ada tersebut membuat pengaturan perikanan lebih banyak mengatur operasional nelayan tangkap dan sangat sedikit mengatur mengenai pembudi daya ikan. Ketiadaan peraturan pelakasanaan membuat pelindungan dan pemberdayaan nelayan dilakukan sporadis, insidentil, dan tidak terintegrasi menyelesaikan persoalan substantif masalah nelayan.

Berdasarkan uraian di atas dapat dijelaskan lebih lanjut bahwa motivasi geo-ekonomi merupakan faktor terpenting untuk melihat urgensi pemerintah dalam melakukan perlindungan kepada nelayan, dan pembudidaya ikan. Motivasi geo- ekonomi ini diletakkan pada persoalan kekayaan alam Indonesia yang begitu besar namun belum mampu dikelola dengan maksimal oleh bangsa Indonesia. Persoalan yang malah muncul, kegiatan impor menjadi alasan untuk mencukupi kebutuhan nasional, seperti halnya ikan lele, ikan salmon, garam, dan akses penunjang lainnya seperti pakan ikan, obat-obatan ikan, dan bibit ikan. ${ }^{3}$

Otomatis, hal ini akan menurunkan daya beli masyarakat terhadap produk hasil perikanan dalam negeri serta meningkatkan tingkat inflasi ekonomi. Perlindungan dan pemberdayaan ne;ayan dan pembudidaya ikan akan menentukan wajah perikanan dan kelautan kita di kemudian hari. Ruh pemberdayaan masyarakat seakan menyala-nyala dalam kebijakan ini dan pemerintah diibaratkan sebagai benteng untuk mem-proteksi "serangan" ekonomi pasar bebas.

Kehadiran Undang-Undang No. 7 Tahun 2016 tidak bisa dilepaskan dari adanya tanggung jawab negara terhadap nelayan dan pembudidaya ikan. Salah satu filosofi dasar pembangunan bangsa ialah mewujudkan keadilan sosial

\footnotetext{
${ }^{3}$ http://maritimnews.com/2016/03/kepentingan-nasional-di-balik-uu-perlindungan- nelayan-pembudidaya-ikandan-petambak-garam/2/,diakses tanggal 15 Maret 2019
} 
bagi seluruh rakyat Indonesia. Oleh karena itu, setiap warga negara Indonesia berhak dan wajib sesuai dengan kemampuannya ikut serta dalam pengembangan usaha untuk meningkatkan kesejahteraan.

Atas dasar itulah, pembuat undang-undang pada dasarnya ingin menghadirkan negara bagi upaya perlindungan dan pemberdayaan nelayan, dan pembudi daya ikan.Di samping itu, salah satu filosofi dasar pembangunan bangsa ialah mewujudkan keadilan sosial bagi seluruh rakyat Indonesia. secara filosofis, konsep keadilan bisa saja berbeda-beda. Namun kondisi keadilan khususnya untuk nelayan kecil dan pembudidaya ikan tidak boleh berubah. ${ }^{4}$ Oleh karena itu, setiap warga negara Indonesia berhak dan wajib sesuai dengan kemampuannya ikut serta dalam pengembangan usaha untuk meningkatkan kesejahteraan.

Sejalan dengan amanat Pancasila dan Undang-Undang Dasar Negara Republik Indonesia Tahun 1945, salah satu tujuan pembangunan Perikanan dan kelautan diarahkan, antara lain untuk meningkatkan sebesar-besarnya kesejahteraan nelayan, dan pembudi daya ikan. ${ }^{5}$

Selama ini nelayan, dan pembudi daya ikan telah memberikan kontribusi yang nyata dalam pembangunan Perikanan dan kelautan serta pembangunan ekonomi masyarakat pesisir dan perdesaan. Kontribusi tersebut pada dasarnya tidak hanya dalam sektor ekonomi, lebih jauh, ia juga nyata secara politik dan sosial. ${ }^{6}$ Semua masalah di atas, pada dasarnya ingin menghadirkan negara dengan perlindungannya.

Lahirnya Undang-Undang No 7 Tahun 2016 , pada dasarnya pejawantahan dari maksud tersebut. Setidaknya berangkat dari satu isu penting yang ingin diselesaikan, yakni posisi pesisir, perikanan, dan kelautan yang masih kurang memberikan jaminan kepastian hukum serta keadilan. ${ }^{7}$ Posisi undang-undang tersebut dibahas satu persatu. Mulai dari siapa sesungguhnya yang disebut dengan nelayan, dan pembudi daya ikan Ketidakberdayaan nelayan, dan pembudi

\footnotetext{
${ }^{4}$ Lukman Adam, Telaah Kebijakan Perlindungan Nelayan dan Pembudaya Ikan di Indonesia, Jurnal Kajian, Vol. 20 No. 2, 2015, h. 145-162.

${ }^{5}$ Adwani, Perlindungan Sumber Daya Perikanan Laut sebagai Bentuk Tanggung Jawab Pemerintah Daerah di Perairan Laut Provinsi Aceh, Jurnal Media Hukum, Vol. 18 No. 2, 2011, h. 190-200

${ }^{6}$ Arif Satria, "Lindungi dan Berdayakan Nelayan", Harian Kompas, 17 Maret 2016

${ }^{7}$ Bernhard Limbong, Poros Maritim, Pustaka Margaretha, Jakarta, 2015, terutama bagian pendahuluan
} 
daya ikan disebabkan oleh faktor internal dan eksternal yang membelenggu nelayan.

Kemiskinan struktural dan kurangnya pemahaman terhadap kebutuhan mereka merupakan beberapa factor yang menyebabkan nelayan, dan pembudi daya ikan perlu dilindungi. Kegiatan perlindungan dan pemberdayaan nelayan, dan pembudi daya ikan yang akan diberikan berupaya mengatasi faktor internal dan eksternal di atas, sehingga diharapkan dapat menjadikan nelayan, pembudi daya ikan, dan petambak garam berdaulat dan mandiri di masa yang akan datang. Kegiatan perlindungan dan pemberdayaan nelayan, dan pembudi daya ikan harus mampu memberikan manfaat untuk dapat mengatasi permasalahan yang dihadapi mereka. Kebermanfaatannya harus dapat dirasakan oleh nelayan, dan pembudi daya ikan, bukan untuk saat ini saja, tetapi juga untuk masa yang akan datang. Kegiatan perlindungan dan pemberdayaan nelayan, dan pembudi daya ikan sangat tergantung pada keterpaduan seluruh pemangku kepentingan, baik pemerintah pusat, pemerintah daerah, perbankan, dan masyarakat.

Bentuk kegiatan perlindungan dan pemberdayaan harus dilakukan secara terbuka agar masyarakat dapat ikut serta mengawasi setiap bentuk kegiatan. Keterbukaan kegiatan akan menyebabkan nelayan,dan pembudi daya ikan, dapat

memberikan masukan dan saran bagi pemerintah dan pemerintah daerah mengenai kegiatan dan program yang tepat diberikan bagi nelayan, dan pembudi daya ikan. Sehingga tujuan dari kegiatan tersebut dapat terjadi.

Kegiatan perlindungan dan pemberdayaan nelayan, dan pembudi daya ikan erat kaitannya dengan kegiatan ekonomi nelayan, dan pembudi daya ikan, guna memenuhi kebutuhan hidup, baik primer, sekunder, maupun tersier. Untuk dapat memperoleh hasil yang optimal, maka kegiatan ekonomi dilakukan secara efisien, dimana penggunaan input (sarana produksi) yang rendah akan memperoleh output (hasil) yang besar. Namun, efisien tidak boleh mengesampingkan rasa keadilan, khususnya untuk nelayan buruh, dan pembudi daya ikan kecil,. Mereka tetap harus memperoleh upah/bagi hasil yang wajar dan memenuhi rasa keadilan untuk kebutuhan rumah tangganya. 
Kegiatan nelayan dan pembudi daya ikan dalam menangkap ikan dan membudidayakan ikan harus terus-menerus dilakukan, berkembang dan tidak stagnan. Kegiatan tersebut harus mampu menyesuaikan dengan perkembangan zaman dan teknologi, agar dapat memenuhi kebutuhan hidup anggota keluarganya. Selain itu, kegiatan perlindungan dan pemberdayaan nelayan, pembudi daya ikan, diharapkan mampu menyesuaikan dengan tradisi dan budaya yang selama ini berkembang di masyarakat secara turun-temurun. Budaya dan tradisi tersebut merupakan kearifan lokal yang mampu bertahan dalam modernisasi pembangunan, sehingga keberadaannya perlu diperhatikan.

Nelayan dan pembudi daya ikan dalam melakukan kegiatan usaha sangat tergantung pada keberadaan sumber daya ikan, sehingga kualitas lingkungan, baik yang berada di laut, pesisir, dan perairan harus terjaga. Kualitas lingkungan sangat dipengaruhi oleh aktivitas masyarakat yang ada di daerah hulu, tengah, dan hilir, sebuah kawasan karena merupakan satu kesatuan ekosistem lingkungan. Oleh karena itu, penyelenggaraan perlindungan dan pemberdayaan nelayan, dan pembudi daya ikan, wajib memperhatikan asas kelestarian lingkungan.

\section{Bentuk Perlindungan Dan Pemberdayaan Terhadap Nelayan Dan Pembudi Daya Ikan}

Perlindungan dimaksudkan untuk menegaskan bahwa negara hadir dan tampil membela kepentingan nelayan dan pembudidaya ikan. Sumber utama kemerosotan perikanan tradisional belakangan ini adalah pendekatan eksploitatif dengan pendekatan intensifikasi yang telah terbukti mengalami kegagalan. Pendekatan intensifikasi hanya akan mendorong modernisasi alat tangkap yang justru lebih merusak ekosistem dan hanya berorientasi pada penyuplai permintaan pasar semata.

Makna perlindungan memiliki arti yang sangat politis, karena terkait masalah hak nelayan dan pembudidaya ikan yang harus dijamin perlindungannya oleh negara dan perundang-undangan. Perlindungan tidak hanya pada saat nelayan dan pembudidaya ikan mencari penghidupan di laut 
lepas tapi juga pada saat berada di darat. Di laut bentuk perlindungan dapat berupa pemberian informasi dan petunjuk serta perlindungan bagi nelayan dari berbagai tindakan seperti aksi perompakan, praktek illegal fishing, konflik penggunaan trawl, kegiatan transhipment serta intimidasi, dan kekerasan oleh pihak luar kepada nelayan Indonesia. Sedangkan di darat perlindungan dapat berwujud revitalisasi Tempat Penjualan Ikan (TPI) yang selama ini tidak dikelola secara benar.

\section{a. Bentuk Perlindungan Nelayan Dan Pembudi Daya Ikan}

1) Penyediaan Prasarana dan Sarana Produksi Kegiatan Usaha Nelayan, dan Pembudi Daya Ikan, Untuk nelayan dan pembudi daya ikan, prasarana yang diperlukan berbeda-beda. Prasarana lebih berupa infrastruktur fisik. Prasarana yang dibutuhkan nelayan antara lain stasiun pengisian bahan bakar yang terletak dekat dengan pelabuhan perikanan, pelabuhan perikanan, jalan pelabuhan, jaringan listrik, dan tempat penyimpangan berpendingin. Sedangkan prasarana yang dibutuhkan pembudi daya ikan antara lain lahan dan kolom air (untuk budi daya perikanan di perairan umum dan di laut), saluran pengairan, jalan produksi, jaringan listrik dan pasar, dan tempat penyimpangan berpendingin.

Sarana dalam kegiatan usaha perikanan adalah segala sesuatu yang dapat dipakai sebagai alat untuk memperoleh/meningkatkan sumber daya ikan, antara lain, berupa bahan bakar minyak, air bersih dan es, bibit dan benih. Untuk nelayan dan pembudi daya ikan, sarana yang diperlukan berbeda-beda. Sarana yang dibutuhkan nelayan antara lain kapal dan alat tangkap, bahan bakar minyak, air bersih dan es. Sedangkan sarana yang dibutuhkan pembudi daya ikan antara lain bibit dan benih, pakan, obatobatan dan air bersih.

Beberapa kajian yang dilakukan dalam pengembangan wilayah yang memiliki potensi perikanan, maka prioritas kebijakan pengembangan perikanan yang diperlukan meliputi: ${ }^{8}$

\footnotetext{
${ }^{8}$ Tomi Romadona, T. Kusumastanto, dan A. Fahrudin. Kebijakan Pengembangan Sumber Daya Perikanan Berkelanjutan dan Berperspektif Mitigasi Bencana di Padang Sumatera Barat.Jurnal Kebijakan Sosial Ekonomi Kelautan dan Perikanan, 2012, h. 145 - 154.
} 
1) Penyediaan sarana pelabuhan, TPI, PPI dan fasilitas perikanan lainnya yang kondusif dan berperspektif mitigasi bencana;

2) Pendidikan dan pelatihan bagi nelayan;

3) Bantuan modal usaha bagi nelayan serta masyarakat yang ingin mengembangkan usaha perikanan;

4) Subsidi bahan bakar dan Pusat informasi cuaca dan kebencanaan yang mudah diakses.

Penelitian yang dilakukan oleh Zulham tahun 2008 merekomendasikan alokasi subsidi kepada nelayan harus diberikan lebih teliti dan terarah. Jika subsidi perikanan tersebut diarahkan pada armada penangkapan ikan yang beroperasi pada wilayah dengan potensi ikan sedang dan rendah maka kebijakan tersebut harus dapat mendorong armada tersebut beroperasi keluar dari fishing ground penangkapan yang sekarang. Sementara pada fishing ground dengan potensi ikan yang melimpah subsidi tersebut digunakan sebagai instrumen untuk meningkatkat kapasitas tangkap. ${ }^{9}$

Revitalisasi fungsi TPI (Tempat Pelelangan Ikan) adalah sebentuk upaya menghubungkan nelayan dengan pasar.Dalam pandangan KIARA, revitalisasi fungsi TPI yang tersebar di kampung-kampung nelayan dimaksudkan untuk memenuhi standar minimum pelayanan bagi kepentingan nelayan tradisional. Fungsi-fungsi TPI yang semestinya dijalankan adalah sebagai berikut: (1) penyediaan informasi cuaca; (2) penyediaan informasi mengenai potensi wilayah penangkapan ikan dan harga ikan secara berkelanjutan; (3) sistem pelelangan ikan yang berkeadilan; (4) penyediaan BBM, bibit dan pakan ikan yang mudah diakses, serta (5) kelengkapan penangkapan/budidaya akan bersubsidi; dan (6) tersedianya fasilitas permodalan yang mudah diakses oleh nelayan.

2) Memberikan Jaminan Kepastian Usaha Terhdap Nelayan dan Pembudidaya ikan Keberadaan nelayan dan pembudi daya ikan selalu berkelompok dan berada di pesisir laut atau perairan umum. Lokasi tempat tinggal nelayan/pembudi daya ikan merupakan lokasi tempat

\footnotetext{
${ }^{9}$ Armen Zulham. Dampak Subsidi Terhadap Surplus Produsen dan Total Benefit Perikanan Tangkap Pantura Jawa Tengah.Jurnal Kebijakan Sosial Ekonomi Kelautan dan Perikanan, 2008, h. 1 - 12
} 
menambatkan kapal atau melakukan kegiatan budi daya perikanan. Namun seringkali terjadi, pembangunan sebuah wilayah menafikan keberadaan nelayan/pembudi daya ikan. Ruang tempat nelayan menambatkan kapal atau pembudi daya ikan melakukan kegiatan diatur dalam Undang-Undang No. 27 Tahun 2007 tentang Pengelolaan Wilayah Pesisir dan Pulau-Pulau Kecil melalui penetapan rencana zonasi wilayah pesisir dan pulau-pulau kecil.

Berdasarkan uraian di atas dapat dijelaskan bahwa beberapa hal yang perlu diperhatikan untuk meningkatkan kesejahteraan nelayan dan pembudi daya ikan adalah:

a. meningkatkan mutu ikan segar yang dihasilkan oleh nelayan dan pembudi daya ikan sehingga harganya jauh lebih tinggi dari sekarang;

b. memperkuat industri pengolahan ikan nasional, hal ini dimaksudkan agar ikan hasil produksi nelayan dan pembudi daya ikan dapat terserap industri nasional.

c. penurunan biaya rumah tangga nelayan dan pembudi daya ikan, misalnya dengan meneruskan dan meningkatkan program biaya kesehatan dan pendidikan gratis untuk keluarga nelayan dan pembudi daya ikan. Hal ini sangat diperlukan karena dengan adanya program kesehatan dan pendidikan gratis para nelayan dan pembudi daya ikan dapatmenginvestasikan biaya yang seharusnya untuk menjamin kesehatan dan pendidikan keluarganya untuk meningkatkan permodalan.

d. penurunan biaya produksi perikanan. Misalnya dengan terus meningkatkan jumlah dan kualitas pelayanan stasiun pengisian bahan bakar khusus nelayan dan pembudi daya ikan di seluruh wilayah Indonesia. Hal ini dimaksudkan agar para nelayan dan pembudi daya ikan dapat membeli bahan bakar solar sesuai dengan harga yang ditetapkan oleh pemerintah. Selain itu juga pemerintah perlu mendorong terwujudnya rumah-rumah pakan ikan yang dikelola oleh setiap kelompok pembudi daya ikan dengan bahan baku lokal. Sehingga mereka tidak tergatung lagi dengan pakan pabrik yang harganya jauh dari jangkauan mereka. 
Dengan adanya kebijakan yang komprehensif dan berkesinambungan, kenaikan harga ikan diharapkan berdampak positif terhadap kesejahteraan nelayan dan pembudi daya ikan nasional. ${ }^{10}$ Oleh karena itu, menurut Suhana kondisi yang ideal untuk menciptakan kondisi yang menghasilkan harga ikan yang menguntungkan bagi nelayan dan pembudi daya ikan dilakukan melalui sejumlah cara: ${ }^{11}$

1) membangun sistem pemasaran;

2) jaminan pemasaran ikan;

3) mewujudkan fasilitas pendukung;

4) sistem informasi harga ikan.

Selain menetapkan zonasi dan menciptakan kondisi yang menghasilkan harga ikan yang menguntungkan bagi nelayan dan pembudi daya ikan, maka aspek lain yang perlu dilakukan dalam kepastian usaha adalah memastikan adanya perjanjian tertulis dalam hubungan usaha perikanan, baik antara pemilik/penyewakapal dengan nelayan atau pemiliki/penyewa lahan dengan pembudi daya ikan dalam perjanjian kerja atau bagi hasil. Bagi hasil telah ada pengaturannya dalam Undang-Undang Nomor 16 Tahun 1964 tentang Sistem Bagi Hasil Perikanan sebagai hukum tertulis.

3) Jaminan Risiko Penangkapan dan Pembudidayaan Ikan

Mengantisipasi apabila ada bencana/ resiko bagi nelayan dan pembudidaya ikan akibat peristiwa di atas maka untuk menjamin keberlanjutan usaha perlu mendapat jaminan melalui perlindungan asuransi. Asuransi yang dimaksudkan adalah sebagai jaminan yang akan peroleh bila terjadi resiko yang tidak diinginkan seperti anomali cuaca, banjir dan pasang air laut tinggi/rob dll, sebagai jaminan dalam bentuk asuransi usaha.

Berdasarkan pertimbangan tersebut, maka diperlukan jaminan terhadap risiko penangkapan, pembudidayaan ikan, dan pergaraman akibat bencana alam, wabah penyakit ikan, hilang atau rusaknya sarana penangkapan ikan, dampak perubahan iklim, dan jenis risiko lain yang diatur oleh Menteri. Penjaminan risiko ini melalui pemberian asuransi perikanan bagi nelayan dan pembudi daya ikan,

\footnotetext{
${ }^{10}$ Suhana. Kajian Singkat Dampak Kenaikan Harga Ikan Segar Terhadap Kesejahteraan

Nelayan. Pusat Kajian Pembangunan Kelautan dan Peradaban Maritim, Jakarta, 2010, h. 107

${ }^{11}$ Ibid
} 
dan asuransi pergaraman bagi petambak garam, dan asuransi jiwa bagi nelayan.

4) Penghapusan Praktik Ekonomi Biaya Tinggi

Masalah perizinan ini memang sudah bersifat klasik bagi usaha perikanan tangkap. Bila dibandingkan dengan berbagai negara berkembang lainnya, secara umum Indonesia masih termasuk salah satu negara yang belum efisien dalam masalah pengurusan perizinan usaha, termasuk usaha perikanan tangkap. Apalagi dalam era otonomi daerah sekarang ini, tidak sedikit Pemerintah Daerah yang telah memposisikan perizinan usaha sebagai sumber untuk pemasukan pendapatan asli daerah (PAD). Sebab, mengurus perizinan usaha sebagai sumber PAD sama saja dengan tindakan mengambil pajak atas investasi. Padahal, semestinya yang menjadi objek pajak bukanlah modal usaha, tetapi hasil dari usahanya. Hal ini, tentu menjadi beban tambahan biaya produksi yang harus ditanggung oleh nelayan, yang pada akhirnya juga akan mengurangi pendapatan yang diperoleh nelayan.

Di Indonesia dikenal beberapa macam surat izin yang terkait dengan usaha perikanan tangkap, diantaranya yang paling umum adalah Surat Izin Usaha Perikanan (SIUP), Surat Izin Penangkapan Ikan (SIPI), dan Surat Persetujuan Berlayar (SPB). Namun, proses atau prosedur perizinan usaha perikanan tangkap, utamanya untuk skala usaha menengah ke bawah (kapal berukuran $<30$ GT), hingga kini belum standar dan transparan prosedurnya untuk semua daerah, apalagi di era otonomi daerah saat ini, dimana tidak sedikit pemerintah daerah memposisikan perizinan sebagai sumber pendapatan asli daerah (PAD). Dengan prosedur perizinan usaha yang belum standar dan transparan, cenderung dapat menimbulkan biaya-biaya tidak resmi atau pungutan liar.

\section{b. Bentuk Pemberdayaan Nelayan dan Pembudi Daya Ikan.}

Dalam konteks pemberdayaan nelayan dan pembudidaya, maka negara harus hadir secara aktif;

1) dalam aspek ekonomi, negara membantu menyediakan fasilitas yang memudahkan nelayan dalam menjalankan aktifitas mata pencaharian di laut hingga melakukan proses transaksi penjualan di darat. 
2) penyediaan TPI, pemerintah perlu mengoptimalkan kembali TPI atau pelabuhan yang sudah ada dengan cara melibatkan nelayan di dalam proses pengelolaannya, bukan diserahkan kepada pihak swasta. Demikian pula dengan penentuan harga hasil tangkapan nelayan, negara harus mengontrol dan bukan malah menyerahkannya kepada mekanisme pasar. Sehingga stabilitas harga dapat terjamin dan nelayan tidak dirugikan.

3) dalam aspek sosial, pemberdayaan juga harus mendorong masyarakat, khususnya generasi muda untuk bangga dan tidak malu menjadi nelayan. Karena nelayan adalah sebuah identitas atau pekerjaan yang sudah ada dan melekat sejak turun temurun, oleh karenanya secara sosial nelayan harus solid. Eksistensi nelayan tidak hanya sekedar dihitung tapi juga benar-benar diperhitungkan baik secara kuantitatif maupun kualitatif. Dalam kaitan ini maka negara harus memberikan apresaisi dan prioritas bagi nelayan untuk lebih diperhatikan tingkat kehidupan dan kesejahteraannya.

4) secara kultural, tata cara penangkapan yang dilakukan oleh nelayan secara turun temurun yang didasarkan pada pengetahuan dan kearifan lokal, harus terus dijaga dan dipertahankan sebagai bagian dari upaya menjaga keseimbangan ekosistem wialyah pesisir dan laut. Untuk itu negara harus memberikan apresiasi dan proteksi terhadap local wisdom yang ada di masing-masing daerah.

Terkait dengan upaya memberdayakan nelayan dan pembudi daya ikan, dapat dilakukan melalui bentuk pemberdayaan yang meliputi²:

1) Pendidikan dan Pelatihan

Paradigma pemberdayaan selain memfokuskan segala aspek yang prinsipil dari setiap individu dalam lingkungannya, seperti sumber daya manusia, material dan fisik sampai kepada manajerial yang kemudian biasanya dapat disebut sebagai aspek sosial-budaya, ekonomi, politik, keamanan dan lingkungan ${ }^{13}$. Persoalan peningkatan kapasitas masyarakat

\footnotetext{
${ }^{12}$ Mohammad..Mulyadi, Kemiskinan, Identifikasi Penyebab dan Penanggulangannya, Publica Press. Jakrta, 2014,h. 67-

${ }^{13}$ Budi Ana Rahayu, Pembangunan Perekonomian Nasional Melalui Pemberdayaan
} 
menjadi persoalan tersendiri saat pendidikan masyarakat dalam satu kawasan tertentu salah satunya nelayan, pembudi daya ikan, dan petambak garam diketahui rata-rata pendidikan formalnya terbatas, walaupun sebenarnya kemampuan masyarakat tersebut dalam mencari sumber hidup dan penghidupan memiliki kemampuan yang mumpuni.

Pengembangan kapasitas dapat dilakukan melalui pendidikan dan pelatihan yang disesuaikan dengan kondisi juga karakteristik masyarakat setempat. Rancangan program pendidikan dan pelatihan masyarakat nelayan, pembudi daya ikan, dan petambak garam disesuaikan dengan kebutuhan masyarakat setempat, ini menghindari dari ketidaksesuaian kebutuhan masyarakat tersebut dalam mengimplementasikan ilmu yang mereka dapat guna peningkatan kualitas kehidupan mereka.

Pengembangan nelayan kecil, dan pembudi daya ikan kecil, melalui pendidikan untuk keluarga mereka melalui beasiswa merupakan keharusan pemerintah dan pemangku kepentingan lain dalam membentuk masyarakat nelayan, pembudi daya ikan, dan petambak garam lebih professional.

2) Penyuluhan dan Pendampingan

Setiap daerah memiliki persoalan yang berbeda pula. nelayan, dan pembudi daya ikan, dituntut untuk bisa mengidentifikasi persoalan yang paling mendasar terhadap kesulitan yang terus dialami komunitasnya. Keterlibatan masyarakat dalam mengidentifikasi persoalan yang ada dalam lingkungan mereka merupakan fondasi dasar dari pemberdayaan itu sendiri. Keberadaan penyuluh sebagai penumbuh semangat keswadayaan pada individu, kelompok masyarakat sangat dibutuhkan. Memberikan bantuan nelayan, dan pembudi daya ikan untuk lebih mengenal dan menggali segala potensi yang ada pada diri mereka dan lingkungan tempat mereka tinggal. Mendorong individu dan masyarakat untuk mencari kesempatankesempatan baru dalam memperbaiki keadaannya.

Penyuluh dan pendamping sebagai fasilitator berfungsi sebagai pemberi motivasi, kesempatan dan dukungan bagi masyarakat. Melakukan negoisasi, mediasi, memberi dukungan, membangun konsensus bersama, 
serta melakukan pengorganisasian serta pemanfaatan sumber. Memberikan masukan positif dan direktif berdasarkan pengetahuan dan pengalamannya serta bertukar gagasan dengan pengetahuan dan pengalaman masyarakat yang didampinginya. Membangkitkan kesadaran masyarakat, menyampaikan informasi kekinian, melakukan konfrontasi, termasuk menyelenggarakan pelatihan kepada masyarakat Kemauan, kemampuan dari penyuluh dan pendamping tentunya menjadi penting dalam melakukan pemberdayaan masyarakat. Kemampuan menjalankan tugas-tugas teknis yang mengacu pada keterampilan praktis menjadi penting sebagai penyuluh dan pendamping. ${ }^{14}$

3) Kemitraan Dalam usaha

Untuk mencapai peningkatan kemampuan usaha kecil menjadi mandiri dan tangguh dalam kaitannya dengan pemberdayaan, kemitraan yang dilakukan kepada nelayan kecil, dan pembudi daya ikan kecil, menjadi kewajiban Pemerintah dan Pemerintah Daerah dalam memfasilitasi hal tersebut. Kemitraan yang dimaksud dalam usaha perikanan adalah memberikan jalan, kesempatan serta peluang pemasaran, permodalan, peningkatan sumber daya manusia serta teknologi kepada nelayan dan pembudi daya ikan.

4) Penyediaan fasilitas pembiayaan dan permodalan

Masalah yang akan terus menjadi persoalan nelayan kecil, dan pembudi daya ikan kecil, adalah modal yang terbatas menyangkut pemenuhan prasarana dan sarana produksi perikanan. Selain itu persoalan bunga pinjaman yang cukup tinggi dan keterbatasan nelayan, dan pembudi daya ikan, dalam memenuhi persyaratan pengajuan kredit. Persoalan modal yang dihadapi nelayan,dan pembudi daya ikan sebenarnya dapat dilakukan dengan keikutsertaan badan usaha swasta dengan memberikan sebagaian keuntungannya untuk memberikan bantuan modal kepada mereka sebagai tanggung jawab perusahaan tersebut kepada masyarakat. Tentunya masyarakat nelayan, pembudi daya ikan, dan petambak garam dalam mengelola modal tersebut dapat dilakukan dengan

\footnotetext{
${ }^{14}$ Edi Suharto, Pendampingan Sosial dalam Pemberdayaan Masyarakat Miskin: Konsep dan Strategi, (Disiapkan sebagai bahan bacaan pelatih dalam meningkatkan kemampuan
} 
cara pengelolaan secara kelompok dengan pendampingan dari penyuluh agar dana tersebut dapat digunakan dengan maksimal dan bertanggung jawab.

5) Kemudahan akses ilmu pengetahuan, teknologi, dan informasi

Ketersediaan sarana pengetahuan tentang teknologi dan informasi serta kelembagaan dalam menciptakan sumber daya manusia yang kuat tentunya menjadi salah satu faktor penentu keberhasilan pemberdayaan nelayan, dan pembudi daya ikan, harus ditumbuhkan kesadarannya mengenai kebutuhannya terhadap ilmu pengetahuan, teknologi dan informasi yang baru menyangkut mata pencahariannya.

6) Kelembagaan nelayan, dan pembudi daya ikan

Pentingnya kelembagaan yang ditaati oleh anggota komunitas nelayan, dan pembudi daya ikan, sehingga kepentingan dan tujuan yang telah disepakati bersama dapat dilaksanakan dengan baik serta kapasitas lembaga/organisasi yang memperlihatkan masyarakat untuk bekerjasama dalam memobilisasi sumber-sumber daya yang tersedia guna menyelesaikan masalah-masalah dalam komunitas nelayan,dan pembudi daya ikan. Hal ini tidak terlepas dari peranan individu, kelompok, pemerintah, dan organisasi/lembaga yang tumbuh dari masyarakat mencerminkan orisinalitas daerah tersebut.

Melalui kelembagaan inilah nelayan dan pembudidaya ikan dapat mengembangkan dirinya, memudahkan kelompok untuk mendapatkan akses permodalan dan pasar. Kelembagaan kelompok perlu diperkuat, dibimbing dan didampingi agar kelembagaan kelompok ini nantinya dapat mandiri baik dalam menjalankan usahanya, ataupun dalam mengatasi kesulitan akses permodalan maupun pemasaran.

\section{Penutup}

\section{Kesimpulan}

a. Ratio legis perlindungan dan pemberdayaan terhadap nelayan dan pembudi daya ikan karena nelayan dan pembudi daya ikan pada umumnya dikategorikan miskin, berpendidikan rendah, dan tidak berdaya. Mereka adalah bagian dari warga Negara yang berhak atas 
pengakuan, jaminan, perlindungan, dan kepastian hukum yang adil, serta perlakuan yang sama dihadapan hukum. Secara filosofis memberikan perlindungan terhadap nelayan dan pembudi daya ikan dalam melakukan usahanya supaya bebas atau terhindar dari berbagai permasalahan dan selanjutnya meningkatkan kapasitas dalam berbagai aspek yang menguntungkan mereka, Sementara itu dari aspek sosiologisnya Indonesia merupakan negara kepulauan, dimana sebagian besar nelayan adalah nelayan kecil dengan tingkat kesejahteraan dan pendidikan yang rendah. Kehidupan nelayan didera sederet persoalan krusial. Antara lain masalah serbuan ikan impor dari negara lain yang membanjiri pasar domestik, masalah persediaan BBM untuk melaut.

b. Bentuk perlindungan terhadap nelayan dan pembudidaya ikan berupa penyediaan prasarana dan sarana produksi kegiatan usaha, berupa alat tangkap ikan, kapal, dan/atau pelabuhan, lahan dan kolom air, serta saluran pengairanm, memberikan jaminan kepastian usaha, jaminan risiko penangkapan dan pembudidayaan ikan dan penghapusan praktik ekonomi biaya tinggi. Sementara pemberdayaan nelayan dan pembudidaya ikan dilakukan dengan cara peningkatan kapasitas nelayan dan pembudidaya ikan melalui pendidikan dan pelatihan, menumbuhkan semangat keswadayaan nelayan dan pembudidaya ikan melalui penyuluhan dan pendampingan, memberi kesempatan serta peluang pemasaran, permodalan, peningkatan sumber daya manusia serta teknologi kepada nelayan dan pembudi daya ikan melalui kemitraan Penyediaan fasilitas pembiayaan dan permodalan, Kemudahan akses ilmu pengetahuan, teknologi, dan informasi, dan Kelembagaan nelayan, dan pembudi daya ikan.

\section{Saran}

a. Pemerintah Daerah Provinsi Kalimantan Utara harus membuat suatu peraturan pelaksana dari Undang-Undang Nomor 7 Tahun 2016 berupa Peraturan Daerah (Perda). Dalam Perda nantinya seharusnya memuat semua jenis perlindungan terhadap nelayan kecil di wilayah Provinsi Kalimantan Utara. Perda perlindungan nelayan kecil 
Provinsi Kalimantan Utara inilah yang akan menjadi pijakan dari Pemerintah Daerah melalui alat kelengkapannya memberikan perlindungan kepada nelayan kecil di Wilayah Perairan Provinsi Kalimantan Utara.

b. Pemerintah Pusat dan Pemerintahan Provinsi Kalimantan Utara tidak boleh tebang pilih dalam memberikan perlindungan kepada para nelayan dan pembudidaya ikan baik itu yang punya kartu nelayan atau bukan,tergabung dalam kelompok nelayan atau bukan. Semuanya haruslah diberikan perlindungan kepada nelayan dan pembududaya ikan. Mereka mempunyai hak yang sama untuk mendapatkan perlindungan dari negara. jangan sampai karena syarat administrasi sebagian nelayan yang tidak dapat melengkapi menjadi tidak dapat dilindungi oleh pemerintah.

\section{REFERENSI}

Marzuki, Peter Mahmud Karakteristik Ilmu Hukum, Yuridika,-Jurnal IlmuHukum Fakultas Hukum Universitas Airlangga Surabaya, Volume 23, No. 2 , Mei - Agustus 2008

Lukman Adam, Telaah Kebijakan Perlindungan Nelayan dan Pembudaya Ikan di Indonesia, Jurnal Kajian, Vol. 20 No. 2, 2015, h. 145-162.

Adwani, Perlindungan Sumber Daya Perikanan Laut sebagai Bentuk Tanggung Jawab Pemerintah Daerah di Perairan Laut Provinsi Aceh, Jurnal Media Hukum, Vol. 18 No. 2, 2011, h. 190-200

Limbong, Bernhard, Poros Maritim, Pustaka Margaretha, Jakarta, 2015,

Tomi Romadona, T. Kusumastanto, dan A. Fahrudin. Kebijakan Pengembangan Sumber Daya Perikanan Berkelanjutan dan Berperspektif Mitigasi Bencana di Padang Sumatera Barat.Jurnal Kebijakan Sosial Ekonomi Kelautan dan Perikanan, 2012

Zulham, Armen Dampak Subsidi Terhadap Surplus Produsen dan Total Benefit Perikanan Tangkap Pantura Jawa Tengah.Jurnal Kebijakan Sosial Ekonomi Kelautan dan Perikanan, 2008, 
Suhana. Kajian Singkat Dampak Kenaikan Harga Ikan Segar Terhadap Kesejahteraan Nelayan. Pusat Kajian Pembangunan Kelautan dan Peradaban Maritim, Jakarta, 2010,

Mohammad..Mulyadi, Kemiskinan, Identifikasi Penyebab dan Penanggulangannya, Publica Press. Jakrta, 2014,

Budi Ana Rahayu, Pembanguna Perekonomian Nasional Melalui Pemberdayaan Masyarakat Desa, http://web.iaincirebon.ac.id/ebook/moon/Mixed/Pemberdayaanmasyarakat-desa.pdf, diakses pada 28 Maret 2019

Suharto, Edi, Pendampingan Sosial dalam Pemberdayaan Masyarakat Miskin: Konsep dan Strategi, (Disiapkan sebagai bahan bacaan pelatih dalam meningkatkan kemampuan (capacity building) para pendamping sosial keluarga miskin pada proyek ujicoba model Pemandu di Lampung, Jateng dan NTB),

http://www.policy.hu/suharto/modul a/makindo 32.htm, diakses pada 23 April 2019.

Undang-Undang Republik Indonesia Nomor 31 Tahun 2004 tentang Perikanan (Lembaran Negara Republik Indonesia Tahun 2004 Nomor 118,( Tambahan Lembaran Negara Republik Indonesia Nomor 4433)

Undang-Undang Republik Indonesia Nomor 45 tahun 2009 Tentang Perubahan Atas Undangundang Nomor 31 Tahun 2004 Tentang Perikanan, (Lembaran Negara Republik Indonesia Tahun 2009 Nomor 154, Tambahan Lembaran Negara Republik Indonesia Nomor 5073)

Undang-Undang Republik Indonesia Nomor 27 Tahun 2007 tentang Pengelolaan Wilayah Pesisir dan Pulau-Pulau Kecil (Lembaran Negara Republik Indonesia Tahun 2007 Nomor 84, Tambahan Lembaran Negara Republik Indonesia Nomor 4739)

Undang-Undang Republik Indonesia Nomor 1 Tahun 2014 Tentang Perubahan Atas Undang-Undang Nomor 27 Tahun 2007 Tentang Pengelolaan Wilayah Pesisir Dan Pulau-Pulau Kecil (Lembaran Negara Republik Indonesia Tahun 2014 Nomor 2, Tambahan Lembaran Negara Republik Indonesia Nomor 5490, ) 
Undang-Undang Republik Indonesia Nomor 7 Tahun 2016 Tentang Perlindungan Dan Pemberdayaan Nelayan, Pembudi Daya Ikan, Dan Petambak Garam (Lembaran Negara Republik Indonesia Tahun 2016 Nomor 68, Tambahan Lembaran Negara Republik Indonesia Nomor 5870)

Undang-Undang Republik Indonesia Nomor 23 Tahun 2014 Tentang

Pemerintahan Daerah, (Lembaran Negara Republik Indonesia Tahun 2014 Nomor 244, Tambahan Lembaran Negara Republik Indonesia Nomor 5587)

Peraturan Pemerintah Nomor 50 Tahun 2015 tentang Pemberdayaan Nelayan Kecil dan Pembudidaya-Ikan Kecil (Lembaran Negara Republik Indonesia Tahun 2015 Nomor 166, Tambahan Lembaran Negara Republik Indonesia Nomor 5719). 